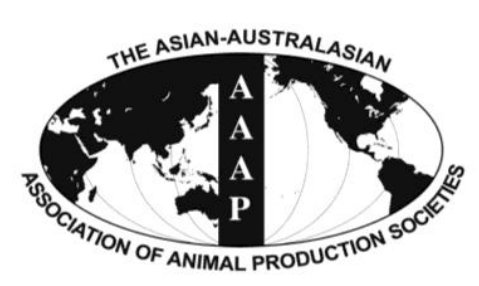

\title{
Energy Requirements in Early Life Are Similar for Male and Female Goat Kids
}

\author{
T. F. V. Bompadre, O. Boaventura Neto, A. N. Mendonca, S. F. Souza, D. Oliveira,
}

M. H. M. R. Fernandes, C. J. Harter, A. K. Almeida, K. T. Resende, and I. A. M. A. Teixeira*

Department of Animal Science, UNESP, Universidade Estadual Paulista, Jaboticabal, SP 14884-900, Brazil

\begin{abstract}
Little is known about the gender differences in energetic requirements of goats in early life. In this study, we determined the energy requirements for maintenance and gain in intact male, castrated male and female Saanen goat kids using the comparative slaughter technique and provide new data on their body composition and energy efficiency. To determine the energy requirements for maintenance, we studied 21 intact males, 15 castrated males and 18 females $(5.0 \pm 0.1 \mathrm{~kg}$ initial body weight (BW) and $23 \pm 5 \mathrm{~d}$ of age) using a split-plot design with the following main factors: three genders (intact males, castrated males, and females) and three dry matter intake levels (ad libitum, 75\% and 50\% of ad libitum intake). A slaughter group included three kids, one for each nutritional plane, of each gender, and all three animals within a group were slaughtered when the ad libitum kid reached $15 \mathrm{~kg}$ in BW. Net energy requirements for gain were obtained for 17 intact males, eight castrated males and 15 females $(5.1 \pm 0.4 \mathrm{~kg}$ BW and $23 \pm 13 \mathrm{~d}$ of age). Animals were fed ad libitum and slaughtered when they reached 5, 10, and $15 \mathrm{~kg}$ in BW. A digestion trial was performed with nine kids of each gender to determine digestible energy, metabolizable energy and energy metabolizability of the diet. Our results show no effect of gender on the energy requirements for maintenance and gain, and overall net energy for maintenance was $205.6 \mathrm{~kJ} / \mathrm{kg}^{0.75} \mathrm{empty} \mathrm{body}$ weight gain (EBW) $\left(170.3 \mathrm{~kJ} / \mathrm{kg}^{0.75} \mathrm{BW}\right)$ from 5 to $15 \mathrm{~kg} \mathrm{BW}$. Metabolizable energy for maintenance was calculated by iteration, assuming heat production equal to metabolizable energy intake at maintenance, and the result was $294.34 \mathrm{~kJ} / \mathrm{kg}^{0.75} \mathrm{EBW}$ and $\mathrm{k}_{\mathrm{m}}$ of 0.70 . As BW increased from 5 to $15 \mathrm{~kg}$ for all genders, the net energy required for gain increased from 9.5 to $12.0 \mathrm{~kJ} / \mathrm{g}$ EBW gain (EWG), and assuming $\mathrm{k}_{\mathrm{g}}=0.47$, metabolizable energy for gain ranged from 20.2 to $25.5 \mathrm{~kJ} / \mathrm{g}$ EWG. Our results indicate that it is not necessary to formulate diets with different energetic content for intact male, castrated male and female Saanen goat kids weighing from 5 to $15 \mathrm{~kg}$. (Key Words: Body Composition, Comparative Slaughter, Gender, Growth, Intake, Metabolism)
\end{abstract}

\section{INTRODUCTION}

The lifelong development and productive performance of goats depends on their receiving adequate nutrition from birth, which requires accurate information about the energy and nutrient requirements of kids during their early life. Younger animals have greater rates of protein and mineral deposition, owing to faster muscle and bone growth rates, whereas fat deposition increases as the animals age (Lawrence et al., 2012). Such differences in deposition affect the relative proportion of tissue accumulation and, therefore, also influence body composition and net energy

\footnotetext{
* Corresponding Author: I. A. M. A. Teixeira. Tel: +55-16-32092682, Fax: +55-16-3209-2682, E-mail: izabelle@fcav.unesp.br Submitted Feb. 25, 2014; Revised Jun. 6, 2014; Accepted Jun. 29, 2014
}

requirements (Shahin et al., 1993).

It has been recognized that gender (castrated or intact males or females) influences the growth of body tissues, carcass composition and gain efficiency (Chizzotti et al., 2007). Previous research has shown that testosterone determines growth rates in males in conjunction with leaner carcasses and greater muscle mass, which result in greater energy requirements (Purchas et al., 1991; Paulino et al., 2009). Previous estimates of the gender-specific energetic requirements of goats have relied on the use of a correction factor from cattle, i.e., a 15 percent difference between intact males vs. females and male castrates (Sahlu et al., 2004, NRC, 2007) although no studies have examined the effect of sex under the same experimental conditions.

Although the nutrient requirements recommended by 
the NRC (2007) have been adopted to formulate diets around the world, its equations were based on the relationship between metabolizable energy intake (MEI) and daily gain and did not account for changes in body composition. Additionally, the current NRC recommendations (NRC, 2007) do not consider the influence of genotype and gender on the energy requirements of suckling goat kids. Therefore, the objective of this study was to determine the energy requirements for maintenance and gain in intact male, castrated male and female dairy goats and to investigate their body composition and energy efficiency in early life.

\section{MATERIALS AND METHODS}

\section{Animals and management}

The experiment was conducted at the Goat Facility of the Universidade Estadual Paulista/Jaboticabal (UNESP, São Paulo, Brazil). Humane animal care and handling procedures were conducted in accordance with the requirements of the University's Animal Care Committee (Comissão de Ética e Bem Estar Animal, CEBEA) under protocol number 004972-09.

Animals were randomly allocated to two trials; the first of which was designed to determine the energy requirements for maintenance and the second to determine the requirements for gain. During the pre-experimental period (from birth to $5 \mathrm{~kg}$ body weight [BW]), newborns were fed goat colostrum (first 3 days of life) and goat milk twice a day at 07:00 and 17:00 h, using an individual feeder bottle, for a total intake of $1.5 \mathrm{~L}$ of milk/d.

During the experimental period, goat kids continued receiving milk until they were weaned at $50 \mathrm{~d}$ of age. In the first 30 days of life, the total amount of milk was split into two equal meals per day. After that period, milk was fed once a day in the afternoon to stimulate the intake of solid feed, which was provided from the seventh day of life onwards. During the pre-weaning period, milk was fed by individual feeder bottle, so the daily intake of milk and solid feed were computed separately. All animals had free access to fresh water.

The composition of the milk is shown in Table 1 . Beginning in the pre-weaning period, all kids received the same experimental diet that was formulated to meet the nutritional requirements set by the NRC (2007) for a gain of $150 \mathrm{~g} / \mathrm{d}$. The experimental diet (Table 1) was comprised of dehydrated corn (Zea mays), cracked corn grain, soybean (Glycine max) meal, molasses, soybean oil, limestone, and a mineral supplement. Dehydrated corn plants consisted of whole corn plants (60\% to $70 \%$ moisture) chopped when the kernel milk line was approximately two-thirds of the way down the kernel. The chopped material was air dried for approximately $72 \mathrm{~h}$ or until it reached $8 \%$ to $10 \%$ moisture, and the dried chopped material was then ground to pass through a 4-mm screen (Wiley-type mill).

Feed ingredients, orts and feces samples were dried at $60^{\circ} \mathrm{C}$ to $65^{\circ} \mathrm{C}$ for $72 \mathrm{~h}$ and ground through a $1-\mathrm{mm}$ screen using a Wiley mill (Arthur H. Thomas Co., Philadelphia, PA, USA). They were analyzed to determine fat content (based on the weight loss from the dry sample upon extraction with petroleum ether in a Soxhlet extraction apparatus for $6 \mathrm{~h}$ (AOAC, 1990, method number 930.15), protein ( $\mathrm{N}$ analysis performed via Dumas combustion using a LECO FP-528LC [LECO Corp., St. Joseph, MI, USA] [Etheridge et al., 1998]), ash (complete combustion in a muffle furnace at $600^{\circ} \mathrm{C}$ for $6 \mathrm{~h}$ (AOAC, 1990, method number 924.05), neutral detergent fiber with amylase and without sulfite (Van Soest et al., 1991), acid detergent fiber (Goering et al., 1970), and gross energy (GE) using a bomb calorimeter (Parr Instrument Co., Moline, IL, USA).

\section{1st Trial: Energy requirement for maintenance}

To determine the maintenance requirements, we studied 54 kids (21 intact males, 15 castrated males and 18 females)

Table 1. Feed, milk, and diet composition

\begin{tabular}{|c|c|c|c|c|c|c|c|c|}
\hline \multirow{2}{*}{ Ingredient } & \multirow{2}{*}{$\%$} & \multirow{2}{*}{$\% \mathrm{DM}$} & \multicolumn{6}{|c|}{$\%$ of DM } \\
\hline & & & $\mathrm{GE}^{1}$ & $\mathrm{CP}$ & Fat & NDF & $\mathrm{ADF}$ & Ash \\
\hline Corn plant hay & 46.9 & 86.9 & 17.3 & 8.8 & 1.6 & 51.0 & 26.3 & 3.7 \\
\hline Soybean meal & 19.3 & 87.7 & 18.9 & 50.6 & 2.1 & 23.5 & 12.4 & 6.4 \\
\hline Corn grain & 25.9 & 86.1 & 17.5 & 9.5 & 4.5 & 15.2 & 4.0 & 1.3 \\
\hline Molasses & 4.3 & 91.9 & 13.4 & 3.4 & 0.06 & - & - & 22.7 \\
\hline Soybean oil & 0.8 & 100.0 & 40.6 & - & - & - & - & - \\
\hline Mineral supplement ${ }^{1}$ & 2.0 & 94.6 & - & 0.1 & - & - & - & 89.7 \\
\hline Limestone & 0.80 & 99.8 & - & 0.1 & - & - & - & 99.7 \\
\hline Milk $^{2}$ & & 11.6 & 25.4 & 28.3 & 32.2 & - & - & 6.1 \\
\hline Diet composition & 100.00 & 87.43 & 14.70 & 14.44 & 2.03 & 28.15 & 13.73 & 6.26 \\
\hline
\end{tabular}

DM, dry matter; GE, gross energy (MJ/kg DM); CP, crude protein; NDF, neutral detergent fiber; ADF, acid detergent fiber.

${ }^{1}$ Composition as declared by the supplier (as fed basis, per kg): $190 \mathrm{~g}$ of Ca; $73 \mathrm{~g}$ of P; $44 \mathrm{~g}$ of Mg; $62 \mathrm{~g}$ of Na; $90 \mathrm{~g} \mathrm{Cl} ; 30 \mathrm{~g} \mathrm{~S} ; 1.35 \mathrm{mg}$ of Zn; $340 \mathrm{mg}$ of $\mathrm{Cu} ; 940 \mathrm{mg}$ of $\mathrm{Mn} ; 1.06 \mathrm{mg} \mathrm{Fe} ; 3 \mathrm{mg} \mathrm{Co} ; 16 \mathrm{mg} \mathrm{I} ; 10 \mathrm{mg} \mathrm{Se}$; max. $730 \mathrm{mg}$ of $\mathrm{F}$.

${ }^{2}$ Metabolizable energy of milk $=20.1 \mathrm{MJ} / \mathrm{kg} \mathrm{DM}$. 
with initial BW of $5.0 \pm 0.1 \mathrm{~kg}$ at $23 \pm 5$ days of age. On the first experimental day, 12 randomly selected kids (six intact males and six females, $4.93 \pm 0.1 \mathrm{~kg}$ and $22 \pm 2$ days of age) were slaughtered for use as an initial baseline. As castration is performed on the tenth day of life, the baseline for intact males was also considered to be the baseline for castrated male kids. The remaining kids were allocated to treatments in a split-plot design with the main factors being three genders (intact males, castrated males and females) and three nutritional planes defined by dry matter intake (DMI, ad libitum, 75\%, and 50\% of ad libitum intake). Dry matter intake consisted of the sum of the solid feed and milk intake. Kids were group fed in 14 slaughter groups, each of which included three kids (one for each nutritional plane) of the same gender, and all three animals within a group were slaughtered when the ad libitum kid reached $15 \mathrm{~kg}$ in BW. The restricted intake amounts were determined daily within each group based on the DMI of the kids in the ad libitum treatment on the previous day.

When the kids fed ad libitum reached approximately $12.12 \pm 0.44 \mathrm{~kg} \mathrm{BW}(56 \pm 4$ days old), a metabolism trial was carried out to determine the digestible energy (DE), the metabolizable energy (ME) and digestible protein contents, and the energy metabolizability of the $\operatorname{diet}\left(\mathrm{q}_{\mathrm{m}}\right)$. The metabolism trial was conducted when animals were consuming solid feed exclusively at three levels of intake (ad libitum, $75 \%$ and $50 \%$ of ad libitum intake). Twentyseven kids (nine intact males, nine castrated males and nine females) were used.

All animals were housed in individual metabolic pens. Feed intake, orts, feces, and urine were collected for five $\mathrm{d}$ after a 3-d adaptation period to the metabolic pens. Urine was acidified daily with $20 \mathrm{~mL}$ of $20 \%$ sulfuric acid. Feeds and orts were sampled daily, and the samples were stored at $-20^{\circ} \mathrm{C}$. Feces and urine were weighed daily, and a $10 \%$ sample was collected and stored at $-20^{\circ} \mathrm{C}$. Composites of the feeds, orts, and feces were dried at $60^{\circ} \mathrm{C}$ to $65^{\circ} \mathrm{C}$ for 72 $\mathrm{h}$ and ground through a $1-\mathrm{mm}$ screen using a Wiley mill. Urine composites were passed through a sieve to remove the large particles, and a subsample was taken for $\mathrm{N}$ determination. Gross energy was determined for the feeds, orts and feces and urine using a bomb calorimeter (Parr Instrument Co., USA). Urine energy was estimated as described by Street (1964), and energy losses by gas production were estimated following Blaxter and Claperton (1965). The DE was computed from the GE of the feeds, orts, and feces. The ME was computed from DE and the GE of urine and energy losses by gas production.

At slaughter, kids were stunned with an electric shock followed by the severing of the jugular vein and carotid artery. All blood was collected and weighed. The gastrointestinal tract (GIT) was weighed before and after it was emptied and flushed with water to determine the empty
BW (EBW) of the animals, which corresponded to the BW at slaughter minus the weight of the contents of the GIT and gallbladder. The whole empty body was initially frozen at $-6^{\circ} \mathrm{C}$ and then cut into small pieces that were ground with a large screw grinder through a plate with $0.32-\mathrm{cm}$ holes. After grinding and homogenization, samples were collected, frozen again, and then freeze-dried. These samples were analyzed to determine dry matter, fat, protein, ash and GE content as previously described.

Maintenance requirements were calculated using the comparative slaughter technique. Heat production (HP, $\mathrm{kcal} / \mathrm{kg}^{0.75}$ of EBW) was calculated as the difference between MEI (kcal/ $\mathrm{kg}^{0.75}$ of EBW) and retained energy (RE, $\mathrm{kcal} / \mathrm{kg}^{0.75}$ of EBW). The antilog of the intercept of the linear regression between the log of HP and MEI was used to estimate the net energy requirement $\left(\mathrm{NE}_{\mathrm{m}}, \mathrm{kcal} / \mathrm{kg}^{0.75}\right.$ of EBW; Lofgreen and Garrett, 1968). The maintenance requirement for $\mathrm{ME}\left(\mathrm{ME}_{\mathrm{m}}, \mathrm{kcal} / \mathrm{kg}^{0.75}\right.$ of $\left.\mathrm{EBW}\right)$ was computed by interactively solving the semilog linear regression equation until HP was equal to MEI. Linear regressions (Lofgreen and Garrett, 1968) of the log of HP and MEI were used to calculate the energy utilized for maintenance $\left(\mathrm{k}_{\mathrm{m}}\right)$, which was computed as $\mathrm{NE}_{\mathrm{m}} / \mathrm{ME}_{\mathrm{m}}$. The slope of the regression of RE on MEI above maintenance was assumed to be the partial efficiency of energy utilization for growth $\left(\mathrm{k}_{\mathrm{g}}\right)$.

\section{Statistical analysis}

Data from the trial were analyzed as a split-plot design using a mixed model with gender, nutritional planes and their interaction as fixed effects and the plots nested within gender as a random effect. All analyses were conducted using version 9.2 of the Statistical Analysis System (SAS Institute Inc., Cary, NC, USA). When significantly different, treatment means were compared using Fisher's protected least significant difference. Regression analyses were conducted through MIXED procedures using restricted maximum likelihood estimation methods. Studentized residuals were plotted against predicted values to verify model assumptions. No outliers (studentized residuals $>|2.5|)$ were identified.

\section{2nd Trial: Energy requirements for gain}

Net requirements for gain were obtained using 40 kids (17 intact males, eight castrated males and 15 females) in a completely randomized design. Animals were fed ad libitum. Twelve kids (six intact males and six females), the same as those used at the first trial, were slaughtered when they reached approximately $5 \mathrm{~kg}$ in BW. When the animals reached $10 \mathrm{~kg}$ in $\mathrm{BW}$, six intact males, four castrated males and four females were slaughtered, and the remainder (five intact males, four castrated males and five females) were slaughtered when they reached $15 \mathrm{~kg}$ in BW. 
Slaughter procedures and laboratory analyses were similar to those previously described. Allometric regressions of nutrient $(\mathrm{g})$ or energy $(\mathrm{kJ})$ content of EBW on EBW (Equation 1) were conducted (ARC, 1980):

$$
L O G_{10} Y=\mathrm{a}+\mathrm{b} \times L O G_{10} X
$$

where $\mathrm{Y}=$ total of the nutrient $(\mathrm{g})$ or energy $(\mathrm{kJ})$ in the EBW; $\mathrm{a}=$ intercept; $\mathrm{b}=$ slope; $\mathrm{X}=\mathrm{EBW}(\mathrm{kg})$.

The first differential of Equation (1) with respect to EBW was used to estimate the composition of the gain at various EBW (Equation 2):

$$
\text { Energy }=\mathrm{b} \times 10^{\mathrm{a}} \times E B W^{(\mathrm{b}-1)}
$$

where Energy is the energy concentration per unit of empty body weight gain (EWG, $\mathrm{kg}$ ), and $a$ and $b$ are parameters estimated by Equation (1).

\section{Statistical analysis}

Regressions analyses were conducted through MIXED procedures using restricted maximum likelihood estimation methods. Studentized residuals were plotted against predicted values to verify model assumptions. No outliers (studentized residuals $>|2.5|$ ) were identified.

\section{RESULTS}

\section{Initial body composition}

A regression equation was developed from the baseline measurements to differentiate EBW from BW. For intact and castrated males, we used the proportion of 0.83 of EBW over BW to estimate the initial EBW because we did not find a significant relationship between EBW and BW ( $\mathrm{p}=$ 0.67). For females, we used Equation (3) (root mean square error $[\mathrm{RMSE}]=0.30 ; \mathrm{p}=0.0002)$ :

$$
E B W=-2.02( \pm 0.97)+1.22( \pm 0.36) \times B W
$$

Initial empty body protein $(\mathrm{g})$, fat $(\mathrm{g})$ and energy $(\mathrm{kJ})$ contents were estimated from the initial EBW $(\mathrm{kg})$. Regression coefficients were similar for males and females, so the same equations were used for both genders (Equations 4, 5, and 6).

$$
\begin{aligned}
& L O G_{10} \text { protein } \\
& =2.50( \pm 0.10)+0.84( \pm 0.16) \times L O G_{10} E B W
\end{aligned}
$$

$L O G_{10} f a t=1.10( \pm 0.36)+1.95( \pm 0.56) \times L O G_{10} E B W$

$L O G_{10}$ energy

$=1.16( \pm 0.24)+3.79( \pm 0.15) \times L O G_{10} E B W$
These equations were used to estimate the initial body composition of the kids in the maintenance requirements trial in order to calculate the retention of energy and nutrients.

\section{Performance, body composition and digestibility}

Kids remained in the trial for $82 \pm 6$ days regardless of gender $(p=0.46)$. Performance and body composition did not different among genders but were affected by nutritional plane (Table 2). As expected, average daily gain (ADG), EWG, fat and energy concentration of kids fed ad libitum were greater $(p=0.0001)$ than those of animals on lower nutritional planes.

Protein and fat deposition changed with growth rate. Figure 1 shows that the rate of fat gain over EWG differed among genders $(p=0.02)$ with females having greater fat deposition than intact and castrated male goat kids. Conversely, the rate of protein gain was not affected by gender $(p=0.64$, Figure 1$)$.

The equations to predict the percentage of fat $(\mathrm{FIG}=$ fat in gain as a \% of EWG, Equations 7 and 8) and protein (PIG = protein in gain as a $\%$ of EWG; Equation 9) in the gain from the concentration of $\mathrm{RE}\left(\mathrm{RE}_{\mathrm{c}}, \mathrm{MJ} / \mathrm{kg} \mathrm{EWG}\right)$, shown below, indicate that the contribution of protein to $R_{c}$ did not differ by gender and showed a constant trend as RE in the gain increased (Equation 9). On the other hand, the FIG on $\mathrm{RE}_{\mathrm{c}}$ (Equations 7 and 8) showed an upward trend even at an early age, revealing a lower slope for females and castrated males compared to intact males $(\mathrm{p}<0.001)$.

For intact males:

$F I G=-25.06( \pm 1.78)+3.52( \pm 0.17) \times R E_{c}$

For females and castrated males:

$F I G=-12.53( \pm 3.81)+2.52( \pm 0.35) \times R E_{c}$

For all:

$P I G=30.23( \pm 2.66)-0.48( \pm 0.25) \times R E_{c}$

Figure 2 shows that the proportion of RE deposited as protein (REp) was higher at lower RE and decreased with RE deposition, and it was similar for males and females. Conversely, the proportion of RE deposited as fat (REf) increased with RE deposition, which was more pronounced in females than males.

Because there were no effects of gender on the digestibility of nutrients and energy, Table 3 only shows the effects of the nutritional planes on these variables. The DE and ME of the diet did not differ among treatments and was $10 \mathrm{MJ} / \mathrm{kg}$ dry matter $(\mathrm{DM})$ and $7.8 \mathrm{MJ} / \mathrm{kg} \mathrm{DM}$ on average, respectively. 
Table 2. Effect of feed restriction and gender on performance and body composition of Saanen goat kids

\begin{tabular}{|c|c|c|c|c|c|c|c|c|c|c|c|c|c|}
\hline \multirow{3}{*}{ Variable } & \multicolumn{9}{|c|}{ Nutritional plane $^{1}(\%)$} & \multirow{3}{*}{ SEM } & \multirow{2}{*}{\multicolumn{3}{|c|}{ p-value }} \\
\hline & \multicolumn{3}{|c|}{ Intact males } & \multicolumn{3}{|c|}{ Castrated males } & \multicolumn{3}{|c|}{ Females } & & & & \\
\hline & $a d$ & 75 & 50 & $a d$ & 75 & 50 & $a d$ & 75 & 50 & & G & $\mathrm{R}$ & $\mathrm{G} \times \mathrm{R}$ \\
\hline Initial BW (kg) & 5.0 & 5.0 & 5.1 & 5.2 & 4.8 & 5.1 & 4.9 & 4.9 & 4.7 & 0.10 & 0.45 & 0.57 & 0.57 \\
\hline Final BW (kg) & $15.3^{\mathrm{a}}$ & $12.2^{\mathrm{b}}$ & $9.1^{\mathrm{c}}$ & $15.3^{\mathrm{a}}$ & $9.4^{\mathrm{b}}$ & $10.2^{\mathrm{c}}$ & $14.9^{\mathrm{a}}$ & $11.6^{\mathrm{b}}$ & $9.5^{\mathrm{c}}$ & 0.46 & 0.58 & $<0.0001$ & 0.08 \\
\hline EBW (kg) & $11.8^{\mathrm{a}}$ & $9.3^{\mathrm{b}}$ & $6.8^{\mathrm{c}}$ & $12.2^{\mathrm{a}}$ & $7.2^{\mathrm{b}}$ & $7.8^{\mathrm{b}}$ & $11.7^{\mathrm{a}}$ & $9.1^{\mathrm{b}}$ & $6.9^{\mathrm{b}}$ & 0.88 & 0.92 & $<0.0001$ & 0.05 \\
\hline DMI (g/d) & $315.4^{\mathrm{a}}$ & $247.2^{\mathrm{b}}$ & $167.4^{\mathrm{c}}$ & $360.2^{\mathrm{a}}$ & $209.5^{\mathrm{b}}$ & $194.6^{\mathrm{c}}$ & $362.6^{\mathrm{a}}$ & $255.0^{\mathrm{b}}$ & $181.7^{\mathrm{c}}$ & 30.0 & 0.43 & $<0.0001$ & 0.29 \\
\hline MEI (kJ/ kg EBW) & $647.9^{\mathrm{a}}$ & $585.2^{\mathrm{a}}$ & $440.0^{\mathrm{b}}$ & $716.4^{\mathrm{a}}$ & $576.5^{\mathrm{b}}$ & $479.2^{\mathrm{b}}$ & $792.6^{\mathrm{a}}$ & $638.0^{\mathrm{b}}$ & $475.3^{\mathrm{c}}$ & 24.7 & 0.06 & $<0.0001$ & 0.53 \\
\hline $\operatorname{ADG}(g / d)$ & $128.7^{\mathrm{a}}$ & $89.7^{\mathrm{b}}$ & $52.4^{\mathrm{c}}$ & $114.5^{\mathrm{a}}$ & $55.9^{\mathrm{b}}$ & $59.2^{\mathrm{b}}$ & $129.1^{\mathrm{a}}$ & $86.0^{\mathrm{b}}$ & $59.3^{\mathrm{b}}$ & 6.6 & 0.16 & $<0.0001$ & 0.35 \\
\hline EWG (g/d) & $96.0^{\mathrm{a}}$ & $64.3^{\mathrm{b}}$ & $31.8^{\mathrm{c}}$ & $89.9^{\mathrm{a}}$ & $38.7^{\mathrm{b}}$ & $41.9^{\mathrm{b}}$ & $99.2^{\mathrm{a}}$ & $66.3^{\mathrm{b}}$ & $39.6^{\mathrm{b}}$ & 5.7 & 0.36 & $<0.0001$ & 0.34 \\
\hline Water (\% EBW) & $57.8^{\mathrm{b}}$ & $59.3^{\mathrm{b}}$ & $62.4^{\mathrm{a}}$ & 59.6 & 62.7 & 60.4 & $57.3^{\mathrm{b}}$ & $60.1^{\mathrm{b}}$ & $64.1^{\mathrm{a}}$ & 0.9 & 0.61 & 0.003 & 0.13 \\
\hline Ash (\% EBW) & 5.7 & 5.6 & 6.2 & 5.7 & 6.2 & 5.7 & 5.4 & 5.8 & 6.3 & 0.2 & 0.98 & 0.28 & 0.31 \\
\hline Protein (\% EBW) & 25.3 & 26.1 & 25.9 & 23.7 & 25.2 & 26.1 & 23.8 & 25.2 & 23.3 & 0.6 & 0.13 & 0.25 & 0.68 \\
\hline Fat $(\% \mathrm{EBW})$ & $10.8^{\mathrm{a}}$ & $8.8^{\mathrm{b}}$ & $5.0^{\mathrm{c}}$ & $10.9^{\mathrm{a}}$ & $5.6^{\mathrm{b}}$ & $7.6^{\mathrm{ab}}$ & $13.6^{\mathrm{a}}$ & $8.5^{\mathrm{b}}$ & $5.8^{\mathrm{b}}$ & 1.2 & 0.42 & $<0.0001$ & 0.07 \\
\hline Energy (MJ/kg EBW) & $9.98^{\mathrm{a}}$ & $9.26^{\mathrm{a}}$ & $7.93^{\mathrm{b}}$ & $9.60^{\mathrm{a}}$ & $7.92^{\mathrm{b}}$ & $8.85^{\mathrm{ab}}$ & $10.49^{a}$ & $9.05^{b}$ & $7.52^{b}$ & 0.37 & 0.70 & $<0.0001$ & 0.03 \\
\hline FIG (\% EWG) & $14.0^{\mathrm{a}}$ & $11.8^{\mathrm{ab}}$ & $7.1^{\mathrm{b}}$ & 14.0 & 8.2 & 9.9 & $19.3^{\mathrm{a}}$ & $11.2^{\mathrm{b}}$ & $7.3^{\mathrm{b}}$ & 2.8 & 0.49 & $<0.0001$ & 0.12 \\
\hline PIG (\% EWG) & 25.5 & 27.0 & 29.9 & 22.9 & 33.1 & 28.3 & 23.7 & 25.5 & 20.1 & 5.0 & 0.20 & 0.22 & 0.45 \\
\hline
\end{tabular}

SEM, standard error of the mean; G, gender; R, feed restriction; BW, body weight; EBW, empty BW; DMI, dry matter intake; MEI, metabolizable energy intake; ADF, acid detergent fiber; FIG, fat in gain; PIG, protein in gain; EWG, empty body weight gain.

${ }^{1}$ ad, ad libitum, 75 and $50 \%$ of ad libitum intake.

Distinct lowercase letters in the same row, within group, differ at $\mathrm{p}<0.05$ by least squares means for diet effect.

Distinct uppercase letters in the same row differ at $\mathrm{p}<0.05$ by least squares means for gender effect.

Energy requirements for maintenance and the efficiency of energy utilization

The slope and the intercept of the linear regression of $\log \mathrm{HP}$ on MEI, which was used to estimate $\mathrm{NE}_{\mathrm{M}}$, were not different among genders $(\mathrm{p}=0.16)$, so a single equation (Equation $10 ; \mathrm{p}<0.001$, RMSE $=0.054$ ) was proposed:

\section{$L O G_{10} H P$}

$$
=2.3109( \pm 0.04305)+0.000540( \pm 0.000070) \times M E I
$$

where HP is heat production in $\mathrm{kJ} / \mathrm{kg}^{0.75} \mathrm{EBW}$; and MEI is metabolizable energy intake in $\mathrm{kJ} / \mathrm{kg}^{0.75} \mathrm{EBW}$.

The mean of the antilog of the intercept confidence interval values from Equation 10 resulted in a $\mathrm{NE}_{\mathrm{m}}$ of 205.6 $\mathrm{kJ} / \mathrm{kg}^{0.75} \mathrm{EBW}$ or $170.3 \mathrm{~kJ} / \mathrm{kg}^{0.75} \mathrm{BW}$. The $\mathrm{ME}_{\mathrm{m}}$ was calculated by iteration assuming that HP is equal to MEI at maintenance which resulted in $294.34 \mathrm{~kJ} / \mathrm{kg}^{0.75} \mathrm{EBW}$ and a $\mathrm{k}_{\mathrm{m}}$ of 0.70 .

Equation $11(\mathrm{p}<0.001, \mathrm{RMSE}=56.45)$ shows the regression of $\mathrm{RE}$ on MEI above maintenance. The $\mathrm{ME}_{\mathrm{m}}$, calculated as MEI when RE is zero, was $262.2 \mathrm{~kJ} / \mathrm{kg}^{0.75}$ EBW, which is $10 \%$ less than previously estimated. The $\mathrm{k}_{\mathrm{g}}$, calculated as the slope of Equation 11, was $0.47 \%$.

$$
R E=-124.40( \pm 43.18)+0.474( \pm 0.070) \times M E I
$$

where $\mathrm{RE}$ is $\mathrm{RE}$ in $\mathrm{kJ} / \mathrm{kg} \mathrm{EBW}^{0.75}$, and $\mathrm{MEI}$ is metabolizable energy intake in $\mathrm{kJ} / \mathrm{kg}^{0.75} \mathrm{EBW}$.

MEI was regressed on RE as protein and as fat, and the relationship (Equation 12, p<0.05, RMSE $=85.3$ ) is shown below. No differences were detected between genders. We observed that ME efficiency for protein deposition (1/1.23
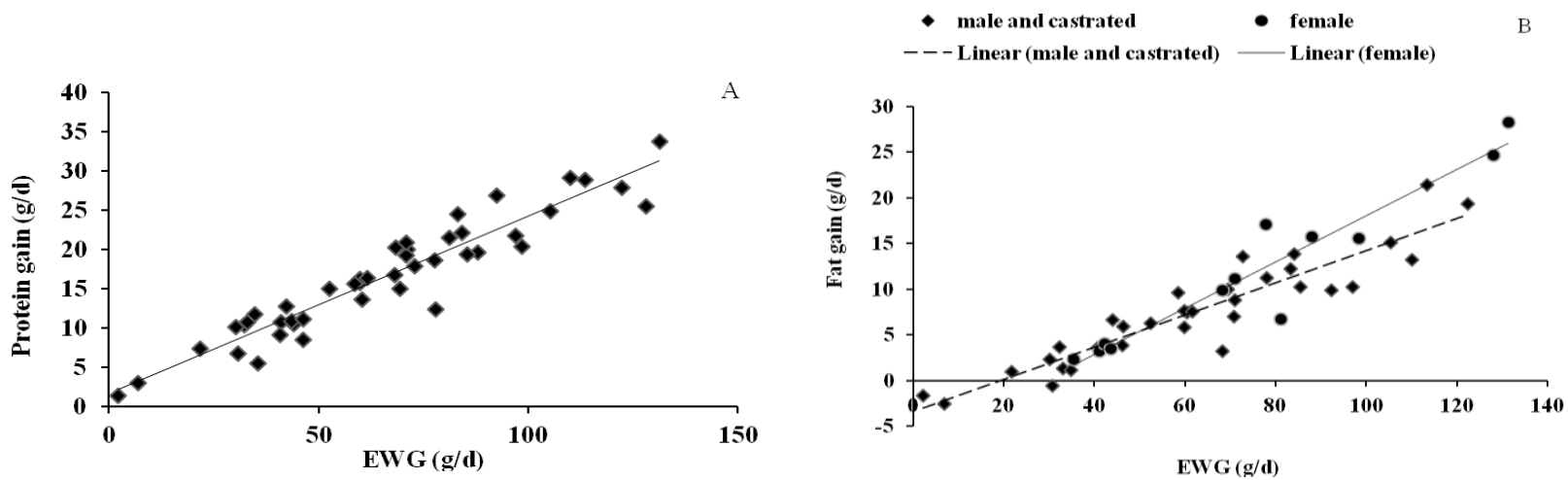

Figure 1. Protein and fat deposition in gain. A. Relationship between protein in gain and empty body weight gain (EWG). Protein in gain $(\mathrm{g} / \mathrm{d})=1.57 \pm 0.88+0.22 \pm 0.01 \mathrm{EWG}(\mathrm{g} / \mathrm{d})$. B. Relationship between fat in gain and EWG. For females: Fat in gain $(\mathrm{g} / \mathrm{d})=$ $-7.26 \pm 1.79+0.25 \pm 0.02 \mathrm{EWG}(\mathrm{g} / \mathrm{d})$. For males and castrates: Fat in gain $(\mathrm{g} / \mathrm{d})=-3.50 \pm 1.38+0.17 \pm 0.02 \mathrm{EWG}(\mathrm{g} / \mathrm{d})$. 

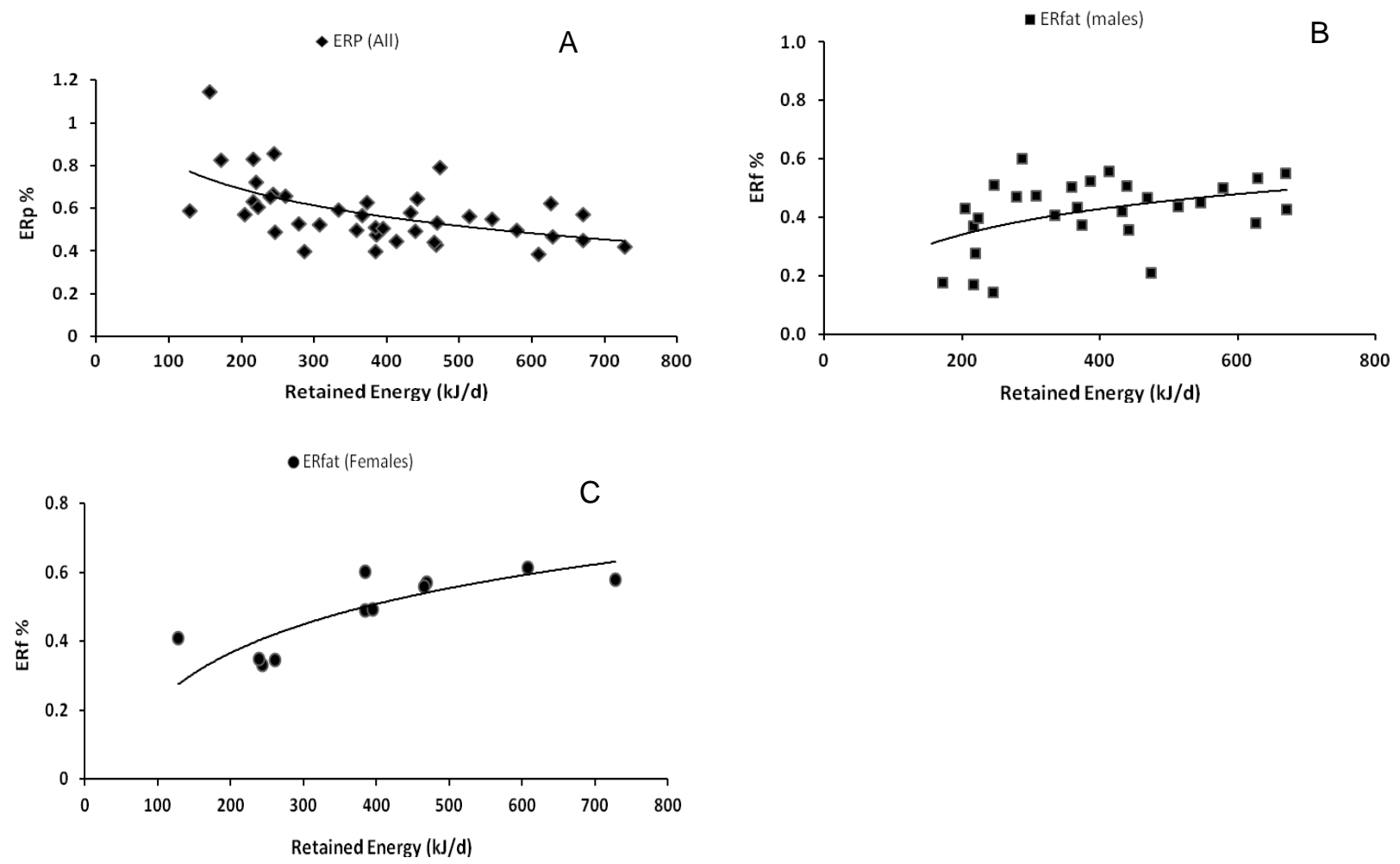

Figure 2. Energy retained as protein (ERp) and as fat (ERf) proportional to retained energy (RE) plotted against retained energy in Saanen kids goats. A. REprot $=0.3937 \times\left(1+121.8 \times \mathrm{RE}^{-0.9585}\right)$. B. For males and castrated males: REfat $=0.4850 \times 1-\mathrm{e}^{-0.00582 \times \mathrm{RE}}$. C. For females: REfat $=0.6411 \times\left(1-\mathrm{e}^{-0.004411 \times \mathrm{RE}}\right)$.

$=0.81)$ was close to that for fat deposition $(1 / 1.21=0.83)$ in goat kids in early life.

$$
\begin{aligned}
M E I= & 404.2( \pm 41.7)+1.23( \pm 0.67) \\
& \times R E p+1.21( \pm 0.42) \times R E f
\end{aligned}
$$

where MEI is metabolizable energy intake in $\mathrm{kJ} / \mathrm{kg}^{0.75}$ EBW; REp is RE as protein in $\mathrm{kJ} / \mathrm{kg} \mathrm{EBW}^{0.75}$; and $\mathrm{REf}$ is retained energy as fat in $\mathrm{kJ} / \mathrm{kg} \mathrm{EBW} \mathrm{E}^{0.75}$.

\section{Energy requirements for growth}

Table 4 depicts the relationship between body fat, energy, and protein content of EBW and the estimated body composition at 5,10 , and $15 \mathrm{~kg}$ in $\mathrm{BW}$. We observed that the proportion of protein did not differ among genders $(\mathrm{p}=$ 0.57 ) and decreased slightly as BW increased. On the other hand, significant differences in the rate of fat deposition, with an increase in the percentage of fat as BW increased, were observed among genders. Specifically, fat deposition

\begin{tabular}{|c|c|c|c|c|}
\hline \multirow{2}{*}{ Variable $^{1}$} & \multicolumn{3}{|c|}{ Nutritional plane $^{1}(\%)$} & \multirow{2}{*}{$\mathrm{p}$} \\
\hline & ad libitum & 75 & 50 & \\
\hline $\mathrm{BW}(\mathrm{kg})$ & $12.7 \pm 0.10^{\mathrm{a}}$ & $9.9 \pm 0.10^{\mathrm{b}}$ & $7.9 \pm 0.11^{\mathrm{c}}$ & $<0.0001$ \\
\hline DMI (g/d) & $248.6 \pm 26.6$ & $181.9 \pm 26.8$ & $158.9 \pm 28.3$ & 0.07 \\
\hline GE $(\mathrm{MJ} / \mathrm{kg})$ & $13.6 \pm 0.15$ & $13.5 \pm 0.16$ & $13.9 \pm 0.16$ & 0.10 \\
\hline GEI (MJ/d) & $3.40 \pm 0.37^{\mathrm{a}}$ & $2.46 \pm 0.37^{\mathrm{ab}}$ & $2.10 \pm 0.39^{\mathrm{b}}$ & 0.05 \\
\hline \multicolumn{5}{|l|}{ Digestibility (\%) } \\
\hline Dry matter & $80.9 \pm 2.0$ & $75.5 \pm 2.0$ & $76.3 \pm 2.2$ & 0.15 \\
\hline Organic matter & $78.3 \pm 2.4$ & $72.2 \pm 2.5$ & $73.6 \pm 2.7$ & 0.22 \\
\hline Crude protein & $68.3 \pm 2.6$ & $61.1 \pm 3.4$ & $68.8 \pm 2.4$ & 0.17 \\
\hline Gross energy & $77.4 \pm 3.1$ & $71.4 \pm 3.2$ & $69.8 \pm 3.4$ & 0.23 \\
\hline $\mathrm{DE}(\mathrm{MJ} / \mathrm{kg})$ & $10.5 \pm 0.4$ & $9.7 \pm 0.4$ & $9.76 \pm 0.5$ & 0.37 \\
\hline $\mathrm{ME}(\mathrm{MJ} / \mathrm{kg})$ & $8.37 \pm 0.6$ & $7.5 \pm 0.5$ & $7.6 \pm 0.6$ & 0.57 \\
\hline
\end{tabular}

Table 3. Digestibility and energy concentration of diets in Saanen kids subjected to feed restriction

BW, body weight; DMI, dry matter intake;GE, gross energy; GEI, gross energy intake; DE, digestible energy; ME, metabolizable energy.

${ }^{1}$ Least squares means followed by their standard error for ad libitum and $75 \%$ and $50 \%$ of ad libitum intake.

${ }^{\mathrm{ab}}$ Distinct lowercase letters in the same row, within group, differ at $\mathrm{p}<0.05$ by least squares means for diet effect. 
Table 4. Allometric equations to estimate body composition (protein, fat, ash and water) and retained energy of female, male and castrated male Saanen kids

\begin{tabular}{|c|c|c|c|c|c|}
\hline \multirow{2}{*}{ Variable $^{1}$} & \multirow{2}{*}{ Allometric equations } & \multicolumn{3}{|c|}{$\mathrm{BW}^{1}(\mathrm{~kg})$} & \multirow{2}{*}{ RMSE $^{2}$} \\
\hline & & 5 & 10 & 15 & \\
\hline EBW (kg) & $\mathrm{EBW}(\mathrm{kg})=-0.58( \pm 0.19)+[0.74( \pm 0.02) \times \mathrm{BW}(\mathrm{kg})]$ & 4.3 & 8.0 & 11.7 & 0.54 \\
\hline Water $(\mathrm{g} / \mathrm{kg}$ of EBW) & $\mathrm{LOG}_{10}$ water $(\mathrm{g})=2.86( \pm 0.01)+\left[0.9163( \pm 0.01) \times \mathrm{LOG}_{10} \mathrm{EBW}(\mathrm{kg})\right]$ & 658.6 & 617.0 & 595.0 & 0.02 \\
\hline Ash (g/kg of EBW) & $\mathrm{LOG}_{10}$ ash $(\mathrm{g})=1.71( \pm 0.03)+\left[1.02( \pm 0.04) \times \mathrm{LOG}_{10} \mathrm{EBW}(\mathrm{kg})\right]$ & 52.5 & 53.3 & 54.0 & 0.02 \\
\hline Protein $(\mathrm{g} / \mathrm{kg}$ of EBW) & $\mathrm{LOG}_{10}$ protein $(\mathrm{g})=2.43( \pm 0.02)+\left[0.96( \pm 0.02) \times \mathrm{LOG}_{10} \mathrm{EBW}(\mathrm{kg})\right]$ & 257.2 & 249.2 & 245.0 & 0.03 \\
\hline Energy $(\mathrm{kJ} / \mathrm{kg}$ of EBW) & $\mathrm{LOG}_{10}$ energy $(\mathrm{kJ})=3.73( \pm 0.03)+\left[1.24( \pm 0.03) \times \mathrm{LOG}_{10} \mathrm{EBW}(\mathrm{kg})\right]$ & 7056 & 8513 & 9447 & 0.04 \\
\hline \multicolumn{6}{|l|}{ Fat $(\mathrm{g} / \mathrm{kg}$ of EBW) } \\
\hline Female & $\mathrm{LOG}_{10}$ fat $(\mathrm{g})=0.99( \pm 0.10)+\left[2.27( \pm 0.15) \times \mathrm{LOG}_{10} \mathrm{EBW}(\mathrm{kg})\right]$ & 41.4 & 112.0 & 194.1 & 0.091 \\
\hline Castrated and intact male & $\mathrm{LOG}_{10}$ fat $(\mathrm{g})=1.33( \pm 0.07)+\left[1.62( \pm 0.08) \times \mathrm{LOG}_{10} \mathrm{EBW}(\mathrm{kg})\right]$ & 43.3 & 70.3 & 92.0 & \\
\hline
\end{tabular}

BW, body weight; RMSE, root mean square error; EBW, empty BW.

${ }^{1}$ Calculated from equations.

was higher in females. However, such differences were not reflected in the levels of retained energy, which also increased as BW increased, but were not different among genders $(p=0.42)$.

Figure 3 illustrates the $\mathrm{NE}_{\mathrm{g}}$ of goat kids and shows that energy requirements increased equally from 9.5 to $12.0 \mathrm{~kJ} / \mathrm{g}$ EWG as BW increased from 5 to $15 \mathrm{~kg}$ for males, castrated males and females. Using the $\mathrm{k}_{\mathrm{g}}$ value of $0.47, \mathrm{ME}_{\mathrm{g}}$ ranged from 20.2 to $25.5 \mathrm{~kJ} / \mathrm{g}$ EWG.

Our study indicated that fat deposition in female goat kids of the Saanen breed is higher than in intact and castrated males in the initial stages of growth. However, energy requirements and the efficiency of energy utilization for growth were not affected by gender.

\section{DISCUSSION}

No differences in the maintenance requirements of female, male and castrated male goat kids were detected. Similarly, recent research on cattle has not detected any differences in energy requirements for maintenance among genders (Tedeschi et al., 2002; Chizzotti et al., 2007). These

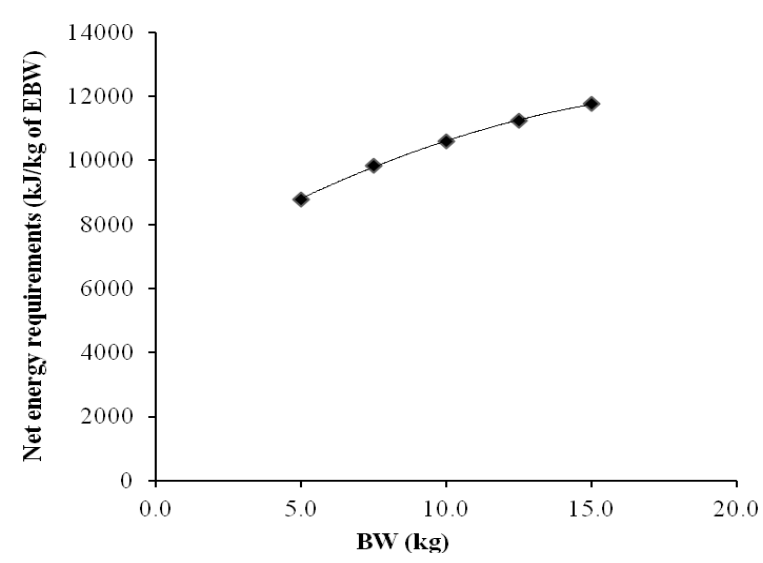

Figure 3. Net energy requirements for growth from 5 to $15 \mathrm{~kg}$ of body weight obtained from the equation: Energy $(\mathrm{kJ} / \mathrm{kg}$ empty BW gain) $=6,691.24 \times \mathrm{EBW}^{0.24}$. EBW, empty body weight. observations are in contrast with current NRC (2007) recommendations that assume that males have $15 \%$ greater $\mathrm{ME}_{\mathrm{m}}$ than females and castrated males. We propose that the lack of a difference between genders reported in the present study could be due to the study of animals of similar weight and age and thus similar organ mass, particularly because the energy expenditure of visceral organs represents a major proportion of basal energy metabolism (Baldwin et al., 1980). The fact that we did not observe differences in DMI further confirms this possibility.

In the present study, $\mathrm{NE}_{\mathrm{m}}\left(170.3 \mathrm{~kJ} / \mathrm{kg}^{0.75} \mathrm{BW}\right)$ was approximately $20 \%$ to $40 \%$ lower than that reported in previous studies (AFRC, 1998; Fernandes et al., 2007; NRC, 2007; Tovar-Luna et al., 2007). The lower $\mathrm{NE}_{\mathrm{m}}$ for kids in this study could be attributed to the lower internal organ mass and lower protein turnover in kids in early life compared to growing kids and mature goats. According to Baldwin (1980), basal metabolic rate (BMR) can be subdivided in terms of the energetic costs of the organs (kidney work, heart work, respiration, nervous and liver functions), which account for $36 \%$ to $50 \% \mathrm{BMR}$, and those of individual cells where protein synthesis accounts for $9 \%$ to $12 \% \mathrm{BMR}$ and lipid synthesis for $2 \%$ to $4 \% \mathrm{BMR}$. Our animals were smaller than those used in previous studies, so their smaller internal organs likely resulted in lesser $\mathrm{NE}_{\mathrm{m}}$. As a consequence of lower $\mathrm{NE}_{\mathrm{m}}$ and greater $\mathrm{k}_{\mathrm{m}}$, our estimates of $\mathrm{ME}_{\mathrm{m}}$ were lower than those reported in previous studies of goats (Fernandes et al., 2007; NRC, 2007; Tovar-Luna et al., 2007).

Because the efficiency of utilization of ME for maintenance $\left(\mathrm{k}_{\mathrm{m}}\right)$ is highly dependent on diet, AFRC (1998) account for the effect of diet by using its metabolizability $\left(\mathrm{q}_{\mathrm{m}}\right)$ to estimate $\mathrm{k}_{\mathrm{m}}$. Thus, in this study, an average $\mathrm{q}_{\mathrm{m}}$ of 0.53 (dietary ME divided by GE) would result in a $\mathrm{k}_{\mathrm{m}}$ of 0.69 , which is consistent with what was calculated interactively (0.70). We also think that $\mathrm{k}_{\mathrm{m}}$ may change due to diet characteristics, but there are other factors involved in $\mathrm{k}_{\mathrm{m}}$ control. We can infer that animal factors may play a role 
in the efficiency of energy use, mainly for gain. We applied the AFRC (1998) equation to estimate $k_{g}$, and the results were $10 \%$ lower $(42 \%)$ than estimates from regressing RE on MEI (0.47). In fact, the previous literature has reported that dietary energy concentration and body composition are the main factors affecting $\mathrm{k}_{\mathrm{g}}$ (Tedeschi et al., 2010).

Although equations to predict the percentage of protein and fat in gain can be useful to understand changes in body composition as a function of biotype and physiological state, they have scarcely been used for goats. Our equation to predict FIG for males (Equation 7) had a lower slope and intercept than that developed by Fernandes et al. (2007) using the Boer crossbred intact male. This difference suggests that Saanen kids have leaner carcasses in early life than growing Boer kids. Additionally, their different biotypes (as dairy and meat goats, respectively) may also contribute to these differences.

The equations developed to estimate REf and REp (Figure 2) indicated that the maximum values for RE as fat were $64.1 \%$ and $48.5 \%$ for females and males, respectively, suggesting that same age females tend to deposit more fat than males. The minimum value for $\mathrm{RE}$ as protein was $39.4 \%$ regardless of gender. This finding indicates that goats have different patterns of tissue deposition compared to cattle (Geay, 1984; Tedeschi et al., 2002; Chizzotti et al., 2007), possibly as a result of differences in the degree of maturity between the cattle species analyzed by these authors and the Saanen goat kids studied here. Therefore, these results further highlight that the extrapolation of metabolic parameters from other ruminant species to goats should be done with caution.

As animals grow, the energy and fat content in EWG increases while the protein content decreases. This pattern was observed in our study as $\mathrm{NE}_{\mathrm{g}}$ was positively correlated with an increase in EWG. As the proportion of protein was nearly constant, fat deposition was the main factor contributing to an increase in body energy. Although females had greater fat deposition in gain, $\mathrm{NE}_{\mathrm{g}}$ was not affected by gender, which is due to similarities in the energy cost of fat and protein synthesis for young ruminants. Conversely, previous studies of cattle (NRC, 2000; Tedeschi et al., 2002; Chizzotti et al., 2007) found different $\mathrm{NE}_{\mathrm{g}}$ among steers, heifers and bulls related to changes in the fat deposits (internal vs carcass fat). The observed lack of a difference in energy requirements for growth among genders for young goats supports the NRC (2007) recommendation of a $\mathrm{ME}_{\mathrm{g}}$ of $23.1 \mathrm{~kJ} / \mathrm{g} \mathrm{ADG}$ for growing dairy kids, regardless of gender.

According to Geay (1984), ME utilization efficiency in protein and fat deposition of bulls weighing from 325 to $500 \mathrm{~kg}$ of $\mathrm{BW}$ ranged from 0.20 to 0.75 , respectively. Conversely, we observed that the efficiency of $\mathrm{ME}$ utilization for protein was close to that for fat deposition
(0.81 and 0.82 , respectively). Thus, we suggest that protein deposition is more efficient in young than mature animals, which is consistent with the priority of tissue deposition throughout life (Lawrence et al., 2012).

In conclusion, although females have a greater tendency to accumulate fat in the carcass, we verified that the contribution of protein to the energy requirements for growth is very similar to the contribution of fat independent of gender in early life. In addition, we suggest that for Saanen kids weighing up to $15 \mathrm{~kg}$, it is not necessary to consider different energy densities in the formulation of diets for different genders.

\section{ACKNOWLEDGMENTS}

This work was financially supported by the Sao Paulo Research Foundation (FAPESP, São Paulo-SP, Brazil, grants \#08/58351-5; 09/06791-4; 12/07177-0). The authors appreciate the assistance of Dr. Normand St-Pierre with the statistical analyses.

\section{REFERENCES}

AFRC. 1998. The Nutrition of Goats. Report n.10. Agricultural and Food Research Council. CAB International, Wallingford, UK.

ARC. 1980. The Nutrient Requirements of Ruminant Livestock: Technical Review. Published on behalf of the Agricultural Research Council by the Commonwealth Agricultural Bureaux, Slough, UK.

AOAC. 1990. Official Methods of Analysis. Vol. I. 15th ed. Association of Official Analytical Chemists, Arlington, VA, USA.

Baldwin, R. L., N. E. Smith, J. Taylor, and M. Sharp. 1980. Manipulating metabolic parameters to improve growth-rate and milk secretion. J. Anim. Sci. 51:1416-1428.

Blaxter, K. L. and J. L. Clapperton 1965. Prediction of amount of methane produced by ruminants. Br. J. Nutr. 19:511-522.

Chizzotti, M. L., S. C. Valadares Filho, L. O. Tedeschi, F. H. M. Chizzotti, and G. E. Carstens. 2007. Energy and protein requirements for growth and maintenance of F-1 Nellore $\mathrm{x}$ Red Angus bulls, steers, and heifers. J. Anim. Sci. 85:1971-1981.

Etheridge, R. D., G. M. Pesti, and E. H. Foster. 1998. A comparison of nitrogen values obtained utilizing the Kjeldahl nitrogen and Dumas combustion methodologies (Leco CNS 2000) on samples typical of an animal nutrition analytical laboratory. Anim. Feed Sci. Technol. 73:21-28.

Fernandes, M. H. M. R., K. T. Resende, L. O. Tedeschi, J. S. Fernandes, H. M. Silva, G. E. Carstens, T. T. Berchielli, I. A. M. A. Teixeira, and L. Akinaga. 2007. Energy and protein requirements for maintenance and growth of Boer crossbred kids. J. Anim. Sci. 85:1014-1023.

Geay, Y. 1984. Energy and protein-utilization in growing cattle. J. Anim. Sci. 58:766-778.

Goering, H. K., C. H. Gordon, R. W. Hemken, P. J. Van Soest, and L. W. Smith. 1970. Analytical measures of heat damaged forage and nitrogen digestibility. J. Dairy Sci. 53:676. 
Lawrence, T., V. Fowler, and J. Novakofski. 2012. Growth of Farm Animals. 3rd ed CABI Oxfordshire, UK.

Lofgreen, G. P. and W. N. Garrett. 1968. A system for expressing net energy requirements and feed values for growing and finishing beef cattle. J. Anim. Sci. 27:793-806.

NRC. 2007. Nutrient Requirements of Small Ruminants: Sheep, Goats, Cervids, and New World Camelids. National Academies Press, Washington, DC, USA.

NRC. 2000. Nutrient Requirements of Beef Cattle: 7th Revised Edition: Update 2000. National Academies Press, Washington, DC, USA.

Paulino, P. V. R., S. C. Valadares Filho, E. Detmann, R. F. D. Valadares, M. A. Fonseca, and M. I. Marcondes. 2009. Body tissue and chemical component deposition in Nellore bulls, steers and heifers. Rev. Bras. Zootec. 38:2516-2524.

Purchas, R. W., A. S. Davies, and A. Y. Abdullah. 1991. An objective-measure of muscularity: Changes with animal growth and differences between genetic lines of southdown sheep. Meat Sci. 30:81-94.

Sahlu, T., A. L. Goetsch, J. Luo, I. V. Nsahlai, J. E. Moore, M. L. Galyean, F. N. Owens, C. L. Ferrell, and Z. B. Johnson. 2004 Nutrient requirements of goats: developed equations, other considerations and future research to improve them. Small Rumin. Res. 53:191-219.
Shahin, K. A., R. T. Berg, and M. A. Price. 1993. The effect of breed-type and castration on tissue-growth patterns and carcass composition in cattle. Livest. Prod. Sci. 35:251-264.

Street, J. C., L. E. Harris, and J. E. Butcher. 1964. Estimating urine energy from urine nitrogen. J. Anim. Sci. 23:1039-1041.

Tedeschi, L. O., C. Boin, D. G. Fox, P. R. Leme, G. F. Alleoni, and D. P. D. Lanna. 2002. Energy requirement for maintenance and growth of Nellore bulls and steers fed high-forage diets. J. Anim. Sci. 80:1671-1682.

Tedeschi, L. O., D. G. Fox, G. E. Carstens, and C. L. Ferrell. 2010. The partial efficiency of use of metabolisable energy for growth in ruminants. EAAP Publication No. 127. pp 519-529 T512.

Tovar-Luna, I., A. L. Goetsch, R. Puchala, T. Sahlu, G. E. Carstens, H. C. Freetly, and Z. B. Johnson. 2007. Efficiency of energy use for maintenance and gain by growing crossbred Boer and Spanish Goats consuming diets differing in forage level. Small Rumin. Res. 67:20-27.

Van Soest, P. J., J. B. Robertson, and B. A. Lewis. 1991. Methods for dietary fiber, neutral detergent fiber, and nonstarch polysaccharides in relation to animal nutrition. J. Dairy Sci. 74:3583-3597. 